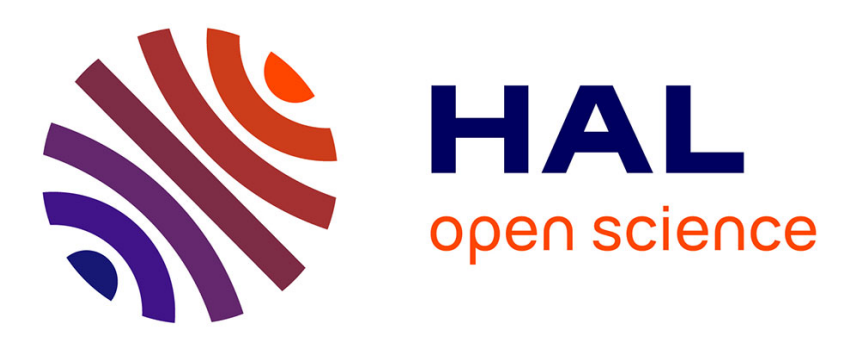

\title{
The eco-frontier paradigm: rethinking the links between space, nature and politics \\ Sylvain Guyot
}

\section{To cite this version:}

Sylvain Guyot. The eco-frontier paradigm: rethinking the links between space, nature and politics.

Geopolitics, 2011, 16 (3), pp.675-706. hal-00520673

\section{HAL Id: hal-00520673 \\ https://hal.science/hal-00520673}

Submitted on 24 Sep 2010

HAL is a multi-disciplinary open access archive for the deposit and dissemination of scientific research documents, whether they are published or not. The documents may come from teaching and research institutions in France or abroad, or from public or private research centers.
L'archive ouverte pluridisciplinaire HAL, est destinée au dépôt et à la diffusion de documents scientifiques de niveau recherche, publiés ou non, émanant des établissements d'enseignement et de recherche français ou étrangers, des laboratoires publics ou privés. 
Accepted for publication in Geopolitics

\title{
The eco-frontier paradigm: \\ rethinking the links between space, nature and politics
}

\author{
Sylvain Guyot \\ UMR 6042 CNRS GEOLAB, Department of Geography, \\ University of Limoges, France \\ Sylvain.guyot@unilim.fr
}

Key-words

Eco-politics, eco-frontiers, space, nature, territory.

\section{Acknowledgments}

Thanks to the referees for their stimulating and helpful comments. 
Table 1: Three generations of eco-frontiers (source: Author)

\begin{tabular}{|c|c|c|c|c|c|}
\hline Generations & $\begin{array}{l}\text { Average start- } \\
\text { ing time }\end{array}$ & $\begin{array}{l}\text { Spatial dif- } \\
\text { fusion }\end{array}$ & $\begin{array}{l}\text { Pileup of main } \\
\text { ideologies of } \\
\text { nature }\end{array}$ & $\begin{array}{l}\text { Geographical/ } \\
\text { Geopolitical } \\
\text { concepts }\end{array}$ & Processes \\
\hline $\begin{array}{l}\text { 1. Imperial } \\
\text { eco-frontiers }\end{array}$ & $\begin{array}{l}\text { From the be- } \\
\text { ginning of the } \\
\text { 18th century }\end{array}$ & $\begin{array}{l}\text { Anglo- } \\
\text { American } \\
\text { colonies } \\
\text { and territor- } \\
\text { ies }\end{array}$ & \multirow{4}{*}{$\begin{array}{l}\text { romantism, pre- } \\
\text { servationism, } \\
\text { conservationism } \\
\text { resourcism, } \\
\text { natural heritage, } \\
\text { deep ecology, } \\
\text { hedonism, } \\
\text { eco-politics, } \\
\text { environmental } \\
\text { justice, } \\
\text { bioregionalism, } \\
\text { eco-marketing } \\
\text { etc. }\end{array}$} & \begin{tabular}{|l|} 
Frontiers, wil- \\
derness, \\
boundaries, \\
natural borders, \\
commodity \\
\end{tabular} & $\begin{array}{l}\text { - romantic discoveries } \\
\text { - greenification of the fronti- } \\
\text { er mythology }\end{array}$ \\
\hline $\begin{array}{l}\text { 2.Geopolitical } \\
\text { eco-frontiers }\end{array}$ & $\begin{array}{l}\text { From the } \\
\text { 1930's }\end{array}$ & \begin{tabular}{|l|} 
Diffusion to \\
various \\
(newly) in- \\
dependent \\
States \\
\end{tabular} & & $\begin{array}{l}\text { Green belts, } \\
\text { buffer zones, } \\
\text { national parks, } \\
\text { international } \\
\text { borders }\end{array}$ & $\begin{array}{l}\text { - eco-frontiers for geopolitic- } \\
\text { al defence of States } \\
\text { - generalisation of protected } \\
\text { areas with the IUCN } \\
\text { - deep ecology as "peacifica- }\end{array}$ \\
\hline \multirow{2}{*}{$\begin{array}{l}\text { 3. Global eco- } \\
\text { frontiers }\end{array}$} & \multirow[t]{2}{*}{ Contemporary } & \multirow[t]{2}{*}{ Worldwide } & & & tion" tool \\
\hline & & & & $\begin{array}{l}\text { World heritage } \\
\text { site, transfron- } \\
\text { tier parks, } \\
\text { green edges, } \\
\text { environmental } \\
\text { networks... }\end{array}$ & $\begin{array}{l}\text { - global ecologist eco-fronti- } \\
\text { er (NGOs) } \\
\text { - dreamers eco-frontiers (vir- } \\
\text { tual and neo-explorers) } \\
\text { - green geo-economics (eco- } \\
\text { logical services) } \\
\text { - ultimate eco-frontiers }\end{array}$ \\
\hline
\end{tabular}


Table 2. Eco-frontiers: invention, representations, and practices by green stakeholders.

\begin{tabular}{|c|c|c|c|c|c|c|c|c|c|c|}
\hline Stakeholder & Identity & Country & Space, place & Scale / Network & Definition & Norms & \begin{tabular}{|l|} 
Utilisation / \\
instrumentalisation
\end{tabular} & $\begin{array}{l}\text { Psycho-mental } \\
\text { representation of } \\
\text { nature }\end{array}$ & $\begin{array}{l}\text { Spatial } \\
\text { representation }\end{array}$ & Conflicts of interest \\
\hline AIRIES $^{1}$ & $\begin{array}{l}\text { Japanese } \\
\text { environmental } \\
\text { research centre }\end{array}$ & $\begin{array}{l}\text { Japan } \\
\end{array}$ & - & $\begin{array}{l}\text { Local - global } \\
\text { International } \\
\text { network }\end{array}$ & $\begin{array}{l}\text { Eco-Frontier Fellowship } \\
\text { Program }\end{array}$ & Call for scholarships & $\begin{array}{l}\text { Increasing knowledge on } \\
\text { global change. Need to } \\
\text { promote international } \\
\text { scientific cooperations. }\end{array}$ & $\begin{array}{l}\text { Scientific vision } \\
\text { (biology, ecology, etc.) }\end{array}$ & & - \\
\hline Biosphere $2^{2}$ & $\begin{array}{l}\text { Environmental } \\
\text { scientists }\end{array}$ & USA & Arizona desert & $\begin{array}{l}\text { Local-intersidereal } \\
\text { International } \\
\text { network }\end{array}$ & $\begin{array}{l}\text { Artificialisation of a } \\
\text { terrestrial eco-system } \\
\text { towards spatial conquest }\end{array}$ & $\begin{array}{l}\text { Overtaking of spatial } \\
\text { and scientific limits }\end{array}$ & $\begin{array}{l}\text { Controversial scientific } \\
\text { interest }\end{array}$ & $\begin{array}{l}\text { Gaïa hypothesis (in a } \\
\text { confined and artificial } \\
\text { way) }\end{array}$ & $\begin{array}{l}\text { The Earth in a } \\
\text { transposable kit. }\end{array}$ & $\begin{array}{l}\text { "The would-be Eden became a } \\
\text { nightmare, its atmosphere gone } \\
\text { sour, its sea acidic, its crops } \\
\text { failing, and many of its species } \\
\text { dying off. Among the survivors } \\
\text { are crazy ants, millions of } \\
\text { them."3 }\end{array}$ \\
\hline Booz \& Co. ${ }^{4}$ & $\begin{array}{l}\text { Management } \\
\text { company }\end{array}$ & USA & Switzerland & $\begin{array}{l}\text { Local-global, } \\
\text { international } \\
\text { network }\end{array}$ & $\begin{array}{l}\text { Eco-frontier as necessary } \\
\text { development tool }\end{array}$ & $\begin{array}{l}\text { Economic competition } \\
\text { through ecological } \\
\text { quality }\end{array}$ & $\begin{array}{l}\text { Environmental quality as key } \\
\text { factor for tourism companies' } \\
\text { location }\end{array}$ & $\begin{array}{l}\text { Cleanliness and } \\
\text { environmental beauty }\end{array}$ & Security of space & $\begin{array}{l}\text { Negative impacts of tourism } \\
\text { incursions }\end{array}$ \\
\hline Circle of Asia $^{5}$ & Travel Agent & $\begin{array}{l}\text { Southeast } \\
\text { Asia }\end{array}$ & Thailand & $\begin{array}{l}\text { National } \\
\text { networking of } \\
\text { places. } \\
\text { International } \\
\text { network. }\end{array}$ & Eco-tourism spots & $\begin{array}{l}\text { Tool for territorial } \\
\text { marketing }\end{array}$ & $\begin{array}{l}\text { Tours } \\
\text { Slogan : Thailand's Wild } \\
\text { Kingdom }\end{array}$ & Ecological hedonism & $\begin{array}{l}\text { The whole country } \\
\text { is considered as a } \\
\text { wild kingdom. }\end{array}$ & $\begin{array}{l}\text { Local and national impacts of } \\
\text { tourism. }\end{array}$ \\
\hline Earth Future $^{6}$ & Preservationist & Canada & $\begin{array}{l}\text { Victoria, } \\
\text { Vancouver } \\
\text { Island }\end{array}$ & $\begin{array}{l}\text { Local-national } \\
\text { Canadian network }\end{array}$ & New ecological struggles & $\begin{array}{l}\text { To go beyond received } \\
\text { ideas on } \\
\text { environmentalism }\end{array}$ & $\begin{array}{l}\text { Radical preservation of nature } \\
\text { (animal rights and destruction } \\
\text { of alien plants) }\end{array}$ & $\begin{array}{l}\text { Radical preservationism } \\
\text { tinted with spiritualism }\end{array}$ & $\begin{array}{l}\text { The world seen } \\
\text { from Vancouver } \\
\text { Island }\end{array}$ & $\begin{array}{l}\text { Activist's actions on sensitive } \\
\text { subjects. }\end{array}$ \\
\hline $\begin{array}{l}\text { Eco-frontier } \\
\text { LTD }^{7}\end{array}$ & $\begin{array}{l}\text { Environmental } \\
\text { industry } \\
\text { company }\end{array}$ & South Korea & Seoul & $\begin{array}{l}\text { International } \\
\text { network }\end{array}$ & $\begin{array}{l}\text { Eco-frontier as a brand for } \\
\text { environmental industrial } \\
\text { solutions }\end{array}$ & $\begin{array}{l}\text { Economic competition } \\
\text { through ecological } \\
\text { quality }\end{array}$ & $\begin{array}{l}\text { To go beyond current green- } \\
\text { washing to deliver proper } \\
\text { green services and } \\
\text { technology. }\end{array}$ & $\begin{array}{l}\text { Eco-marketing and green } \\
\text { geo-economics }\end{array}$ & $\begin{array}{l}\text { The world as a } \\
\text { global brain }\end{array}$ & - \\
\hline $\begin{array}{l}\text { Eco-frontiers } \\
\text { Ranch }^{8}\end{array}$ & Eco-tourism & Poland & $\begin{array}{l}\text { Bieszczady } \\
\text { Mountains } \\
\text { South-east of } \\
\text { Poland, } \\
\text { Ukrainian } \\
\text { border }\end{array}$ & $\begin{array}{l}\text { Local- global } \\
\text { International } \\
\text { network }\end{array}$ & $\begin{array}{l}\text { Nature and landscape of } \\
\text { great interest at the confines } \\
\text { of Poland (Ukrainian and } \\
\text { Slovakian borders), } \\
\text { ecological autarchy } \\
\text { (renewable energies, organic } \\
\text { agriculture, etc.) }\end{array}$ & $\begin{array}{l}\text { Place name and tool of } \\
\text { promotion for eco- } \\
\text { identity }\end{array}$ & $\begin{array}{l}\text { Paying eco-conquest reserved } \\
\text { for a few selected tourists } \\
\text { (vegetarians, outdoor, uneasy } \\
\text { access, etc.). } \\
\text { "Unique place for unique } \\
\text { people" }\end{array}$ & $\begin{array}{l}\text { Desire of preservation } \\
\text { and eco-knowledge/ } \\
\text { eco-control emanating } \\
\text { from a biologist and an } \\
\text { environmentalist }\end{array}$ & $\begin{array}{l}\text { Territorial confines } \\
\text { opened on the } \\
\text { mountains } \\
\text { (transborder } \\
\text { Carpathians) }\end{array}$ & $\begin{array}{l}\text { Old collective system } \\
\text { (acquisition of a former } \\
\text { kolkchoz) versus new private } \\
\text { system. What are the legacies } \\
\text { and the socio-environmental } \\
\text { transformations at stake? }\end{array}$ \\
\hline $\begin{array}{l}\text { Eco-tips / } \\
\text { Dancing Star } \\
\text { Foundation }{ }^{9}\end{array}$ & $\begin{array}{l}\text { Environmental } \\
\text { foundation }\end{array}$ & $\begin{array}{l}\text { Canada, } \\
\text { Dubai, } \\
\text { Mantilla }\end{array}$ & - & $\begin{array}{l}\text { Global } \\
\text { International } \\
\text { network }\end{array}$ & Against violence to animals & $\begin{array}{l}\text { Set-up limits to human } \\
\text { cruelty }\end{array}$ & Vegetarianism & Sanctuarised nature & $\begin{array}{l}\text { Separation between } \\
\text { human and animal } \\
\text { spaces }\end{array}$ & - \\
\hline $\begin{array}{l}\text { Eco-tourist, } \\
\text { users of } \\
\text { WAYN }^{10}\end{array}$ & $\begin{array}{l}\text { Travel photo } \\
\text { blog }\end{array}$ & World & Philippines & $\begin{array}{l}\text { Global } \\
\text { Friend's network. }\end{array}$ & Empty beaches & - & $\begin{array}{l}\text { To be one of the sole } \\
\text { conqueror of the last } \\
\text { ecological frontier }\end{array}$ & Natural paradise & $\begin{array}{l}\text { Inaccessible and } \\
\text { remote area }\end{array}$ & $\begin{array}{l}\text { Contrast between tourism } \\
\text { products and local social reality }\end{array}$ \\
\hline $\begin{array}{l}\text { Fairfax County } \\
\text { federation of } \\
\text { Citizen } \\
\text { Association } \\
\text { (FCFCA) }^{11} \\
\end{array}$ & $\begin{array}{l}\text { Citizens' } \\
\text { association }\end{array}$ & $\begin{array}{l}\text { USA, State } \\
\text { of Virginia }\end{array}$ & Fairfax County & $\begin{array}{l}\text { Local } \\
\text { Regional network }\end{array}$ & $\begin{array}{l}\text { Implementation of new areas } \\
\text { of conservation in the north } \\
\text { of Virginia }\end{array}$ & $\begin{array}{l}\text { Citizen participation in } \\
\text { relation to the } \\
\text { structuring of a } \\
\text { regional park. }\end{array}$ & $\begin{array}{l}\text { Commitment to nature } \\
\text { conservation } \\
\text { (Northern Virginia Regional } \\
\text { Park Authority) }\end{array}$ & Nature conservation & $\begin{array}{l}\text { Bio-regionalism } \\
\text { (regional ecological } \\
\text { specificity) }\end{array}$ & $\begin{array}{l}\text { Conflicts between conservation } \\
\text { versus other uses. }\end{array}$ \\
\hline $\begin{array}{l}\text { Grishino } \\
\text { Ecological } \\
\text { Village }^{12}\end{array}$ & $\begin{array}{l}\text { Russian eco- } \\
\text { village }\end{array}$ & Russia & $\begin{array}{l}\text { Grishino, } 300 \\
\text { km noth-east of } \\
\text { St Petersburg }\end{array}$ & $\begin{array}{l}\text { Local /national } \\
\text { National network }\end{array}$ & $\begin{array}{l}\text { Live in peace with nature on } \\
\text { a forestry extractive front } \\
\text { harmful for local } \\
\text { biodiversity. }\end{array}$ & $\begin{array}{l}\text { Vegetarianism, food } \\
\text { autarky and revival of } \\
\text { local cultures }\end{array}$ & $\begin{array}{l}\text { Eco-conquest, escape from } \\
\text { cities to recover lost } \\
\text { tranquillity. }\end{array}$ & $\begin{array}{l}\text { Forest as "Nature" } \\
\text { needing eco-guards. }\end{array}$ & $\begin{array}{l}\text { Natural and cultural } \\
\text { revival in periphery } \\
\text { of Russian cities. }\end{array}$ & $\begin{array}{l}\text { Conflicts with forestry and with } \\
\text { local people. }\end{array}$ \\
\hline $\begin{array}{l}\text { The Land is } \\
\text { Ours }^{13}\end{array}$ & $\begin{array}{l}\text { Association } \\
\text { fighting for } \\
\text { access to the land }\end{array}$ & $\begin{array}{l}\text { United } \\
\text { Kingdom }\end{array}$ & $\begin{array}{l}\text { Different } \\
\text { countrysides }\end{array}$ & $\begin{array}{l}\text { Local/national } \\
\text { National network }\end{array}$ & $\begin{array}{l}\text { Facilitate access to land for } \\
\text { eco-settlers wishing to } \\
\text { promote ecologically } \\
\text { friendly agriculture. }\end{array}$ & $\begin{array}{l}\text { Rural resistance and } \\
\text { respect of land rights }\end{array}$ & $\begin{array}{l}\text { Land conquest on large } \\
\text { properties motivated by } \\
\text { ecological motives }\end{array}$ & $\begin{array}{l}\text { Rural sustainability } \\
\text { through farmers / nature } \\
\text { balance }\end{array}$ & End of enclosures & $\begin{array}{l}\text { Conflicts with big farmers and } \\
\text { agricultural companies. }\end{array}$ \\
\hline
\end{tabular}




\title{
The eco-frontier paradigm: rethinking the links between space, nature and politics
}

\begin{abstract}
:
There is a gap in the geographical/geopolitical literature about the process that motivates humans to conquer a boundless, timeless and invaluable wilderness in the name of plural ecologies to serve their own political interests in control and territory building by means of 'green gerrymandering'. The ecological frontier (or eco-frontier), a neologism produced by a contemporary greened civil society, can be considered a new paradigm that embraces the mental representations and spatial constructions of eco-conquest without restricting its temporal dimension to the present time. Indeed, the eco-frontier is a genealogical paradigm where new dynamics always revisit old processes. The creation and use of the eco-frontier can illuminate the history of the global territorialisation of nature in the last three centuries. From a spatial point of view, two main understandings of the eco-frontier exist. The first characterises virtual and mental imageries of natural spaces of eco-conquest that are strongly associated with Westernised representations of nature. The second considers eco-frontiers as geographical processes to understand the green dynamics of territorial appropriation and re-conquest. As a genealogical paradigm, the eco-frontier has a specific temporal dynamic that integrates the different historical contexts and political ideologies of nature. Three generations of eco-frontiers (Empire, Geopolitical and Global generations) began at different times and co-exist today, with superposition and percolation. This empirical study shows how contemporary environmentalists and green stakeholders produce specific discourses and representations on global eco-frontiers. The paper focuses on the current territorial domination carried out by contemporary eco-conquerors creating possible new geopolitics.
\end{abstract}

\section{Introduction:}

\section{Eco-frontiers and the "Forest Frontiers Initiative of the World Resource Institute"}

The word "frontier" has three meanings, according to the Thesaurus Dictionary: "An international border or the area along an international border", "A region just beyond or at the edge of a settled area" and "An undeveloped area or field for discovery or research". Intuitively, the ecological frontier (or eco-frontier) meets these three premises in different ways. Thus, how do natural spaces of high ecological value deal with the geopolitics of international borders, beyond the well-researched question of natural borders? ${ }^{14}$ How are the regions at the edge of settled areas coveted and then controlled by ecological actors territorialising a boundless nature? How do eco-frontiers represent a new field for research linking environmental matters to specific political spaces? This paper is the main theoretical article of a themed issue of Geopolitics on eco-frontiers. The aim of this study is to detail these questions and provide reflections and readings from both Francophone and Anglophone geographies. 
The example of the 'Forest Frontiers Initiative of the World Resource Institute' seems relevant to provide some introductory perspectives on ecological frontiers. The World Resource Institute (WRI) is a U.S.-based environmental think tank that goes beyond research to find practical ways to protect the earth and improve people's lives. ${ }^{15}$ Its main donors are corporate companies, such as BP and the BP Foundation, the Caterpillar Foundation, Shell International and the Shell Foundation, and Toyota Motor North America. ${ }^{16}$ Therefore, the goal of WRI, like many other green foundations in the world, is to promote environmental sustainability to compensate for the negative impacts generated by the activities of its main donors. Their main projects are concentrated on natural margins not yet impacted by the extractive industry. One of these projects, the 'Last Frontier Forests', ${ }^{17}$ is dedicated to the preservation of the last remaining primary forests of the world.

Today, just one-fifth of the world's original forest cover remains in large tracts of relatively undisturbed forest, what WRI calls 'frontier forest'. Three countries, Russia, Canada, and Brazil, house almost 70 percent of the world's remaining frontier forest. Forty percent of the forest on Earth today qualifies as frontier forest. According to WRI, the word 'frontier' conjures up notions of new challenges, new lands, or new intellectual endeavours ripe for human exploitation and development. If a frontier is out there, people will not be far behind. The frontier vision, WRI has written, often saw trees as a commodity, at best, or simply an obstacle in the way of progress. Over many centuries, about half of the world's forests--almost 3 billion hectares--were burned, cleared, or cut down. Just one-fifth of the world's original forest cover remains in large undisturbed tracts today, and the cutting has accelerated: about 16 million hectares are cut or burned each year. ${ }^{18}$ For WRI, the frontier is a potential geographical space for invasion. Therefore, the frontier forest is at risk of being destroyed. In promoting the preservation of frontier forests, WRI transforms the idea of 'frontier' from a space of colonisation and exploitation of resources into an ecological area controlled by specific actors belonging to the environmentalist sphere. In fact, according to WRI, in conjunction with several partners (including the World Conservation Monitoring Centre, the World Wildlife Fund, and ninety forest experts), they developed the first map of frontier forest areas (Figure 1), assembling in one place unprecedented location-specific information on current and future threats to forest integrity. According to WRI, frontier forests--large, ecologically intact, and relatively undisturbed natural forests--are likely to survive indefinitely without human assistance. Within these forests, natural ecological and evolutionary processes will continue to generate and maintain the biodiversity upon which we all rely. Frontier forests also contribute a large portion of the ecological services, such as watershed protection and climate stabilisation, which make the planet habitable. They are also home to many of the world's remaining indigenous people. ${ }^{19}$ This typical preservationist discourse relates directly to one of the concepts of ecological frontiers: the case of a boundless and timeless nature supposedly surviving without human assistance, except for some selected eco-settlers--the indigenous people and the ecologists trying to control, territorialise and map this natural space (Figure 1). 
Figure 1: The last remaining forest frontiers in the world

Source: www.globalforestwatch.ca/.../B1a World IFL.png, accessed 21 June 2010.

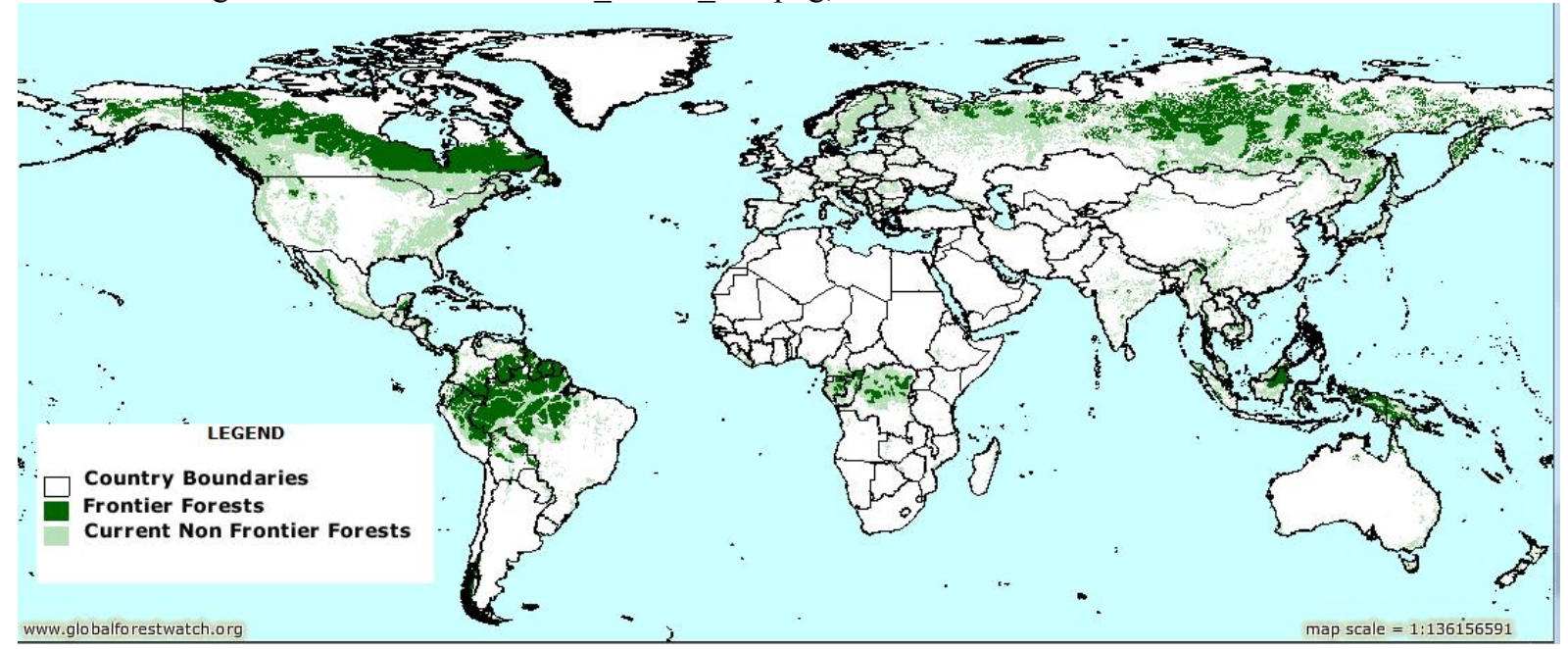

\section{A need for eco-frontiers?}

In the literature, the link between nature and space is always somewhat dualistic and paradoxical, continuing the intrinsic and contradictory divide between nature and culture. A dualism does exist between geographical/geopolitical notions spatialising nature. Some will capture the boundless, timeless, invaluable and non-human sides of nature, like wilderness, vastness, wasteland or eco-tone. Other notions will better capture the territorial imprint made on a bounded, valued and human-controlled nature, like natural borders, green belts, buffer zones, environmental corridors, protected areas or spatialised environmental networks. These two sets of notions are paradoxical. In fact, no one addresses the fact that natural dynamics, such as eco-system mobility and transformation and the human uses of nature, are always related but often diverge in space and time. The wilderness is supposed to be "a wild and uninhabited area left in its natural condition", ${ }^{20}$ but today no single space in the world qualifies for such a description; moreover, the wilderness is a human representation of nature that suits the particular interests of romantic preservationists or explorers. Alternatively, a protected area, like a national park, is "an area of land and/or sea especially dedicated to the protection and maintenance of biological diversity and managed through legal or other effective means". ${ }^{21}$ The socalled "protection and maintenance of biological diversity" is biased, with the bounding of ecosystems in (small) sized reserves and the historically agricultural use of the ecosystems is often replaced by tourism and recreation, negating the timeless dimension of such environments. To date, no concept or paradigm seems to clarify this dualism. There is a gap in the literature about the process that motivates humans to conquer a boundless, timeless and invaluable wilderness, in the name of plural ecologies, to serve their own interests of control and territory building by means of 'green gerrymandering'. The ecological frontier (or eco-frontier), a neologism produced by a contemporary greened civil society, can play the role of an 'umbrella concept' or even of a new paradigm. It can embrace the entire process of eco-conquest, both mentally and spatially, without restricting its temporal dimension. The eco-frontier is a genealogical paradigm in which new dynamics always revisit old processes. For instance, we suggest that the creation of a national park is never an ultimate stage of eco-conquest but can continually be transformed by new ideologies and actors, such as the implementation of 
regional networks of protected areas or the creation of transfrontier parks. Another advantage to finding a new paradigm is that it can include and elucidate all geographical/geopolitical notions that link nature to space. The creation and use of the eco-frontier can clarify the last three centuries of the global territorialisation of nature. Consequently, it is not anachronistic to use a neologism to explain a larger process in time and space. It is a just a way to revisit the past and link it to a complex present.

How do we link the eco-frontier to the current geographical/geopolitical debates in the various notions that link nature to space?

\section{Eco-frontiers: a new paradigm in the field of the space/time of nature}

The paradigm of the eco-frontier revolves around two principal premises, a spatial premise and a temporal premise.

From a spatial point of view, two main understandings of eco-frontiers can be defined. The first understanding of eco-frontiers characterises virtual and mental imageries of available natural spaces of eco-conquest that are strongly associated with Westernised representations of nature. The second premise considers eco-frontiers as geographical processes to understand the green dynamics of territorial appropriation and re-conquest. Here eco-frontiers are processes of green domination over valued territories. Indeed, eco-frontiers are like soft 'frontier areas' or 'pioneer fronts' reshaped by specific ecological dimensions and values. ${ }^{22}$ More precisely, eco-frontiers are places of pristine biodiversity and scarce but valuable natural resources (e.g., water, minerals, forest, and local knowledge). Unstable, highly coveted, and instrumentalised, 'eco-frontiers' are transitory and temporary spaces that are characterised by unique interrelationships between different non-extractive appropriations of ecological resources (conservation, preservation, hedonism, etc.), strongly marked by a sense of place, land conflicts, territorial games, and competing network forces. Eco-frontiers are spaces of ecologist domination.

\footnotetext{
Envisioning nature as an object of conquest or material exploitation has, in turn, created antithetical concerns, among them the belief in nature conservation and environmental sustainability. The frontier is both a boundary and a device for social exclusion, a zone of transition and a new cultural imaginary. ${ }^{23}$
}

From a temporal point of view (and as stated above), eco-frontiers are genealogical processes as well. They have a specific dynamic in time, integrating the different historical contexts and ideologies of nature. Different generations of eco-frontiers started at different times and tend to co-exist today, with superposition and percolation. Using this logic, a younger generation can use and adapt the legacy of the older generation and can evolve, as well, through new principles. The plasticity of this genealogy is high and goes beyond a simple chronology of evolution. In this paper, we will characterise three generations of eco-frontiers (Table 1 below) and look at how geographical/geopolitical concepts rely on each. Then, we will focus on some contemporary aspects of the third generation of eco-frontiers. De facto, an empirical study will show how environmentalists and green stakeholders produce specific discourses and representations on eco-frontiers. A final point will focus on the current territorial domination carried out by contemporary eco-conquerors. 


\section{Three generations of eco-frontiers}

The three generations of eco-frontiers are defined in Table 1 according to two main criteria: the relation to evolving political ideologies of nature and geographical / geopolitical concepts linking space to nature.

The first generation began two centuries ago. It is marked by the imperialism of protectionism over nature, with the 'frontier-type eco-conquest' emanating from large Empires like the United Kingdom and the United States. The second generation is more closely related to the securing of States. It started between the two World Wars, culminating during the Cold War. The third generation is contemporary. It embraces the current success of environmentalist thought on a global scale, driven mainly by international organisations, ONG and civil society. We will present the characteristics of each generation and focus on its theoretical relation to central geographical/geopolitical concepts and debates.

\section{[Table 1 about here]}

\section{First Generation: Imperial eco-frontiers.}

This first generation combines two intricate processes: the romantic traveller's era, with naturalist explorers and romantic artists becoming preservationists; and the expansion of conservationism in the territories of great Empires such as the United Kingdom ${ }^{24}$ and its colonies (mainly Eastern and Southern Africa ${ }^{25}$, Australia, New Zealand and Canada) and the United States and its western frontier territories. ${ }^{26}$

The main geographical/geopolitical concepts that clarify this first generation of the ecofrontier are the frontier, the boundary and the commodification of nature.

In fact, the parallel between frontier and eco-frontier is relevant in the context of this first generation. The wilderness mythology of the frontier includes an aesthetic and ecological dimension in its intellectual representation of the limit between civilisation and savagery. Conversely and contradictorily, the practice of the frontier with the invasion of new territories has led to the widespread destruction of eco-systems. This first generation of the eco-frontier is, then, a result of the ecological failure of the so-called 'Turnerian frontier'. It appears to be like a sort of reclamation of the natural dimension of the mythological frontier (lost in the pioneer extractive economic system) by romantics, naturalists and resourcists through an ecological conquest (eco-conquest). Therefore, this first ecological frontier implementation is very much inspired by key thinkers, such as Thoreau or Emerson, and is symbolised by the establishment of several national parks, such as Yellowstone in the United States in 1872. ${ }^{27}$

[On Thoreau]

His admiration for nature is matched by his own resource-fullness and pride in what he can do. These values have passed into the cultural cortex of societies founded upon a frontier myth and celebrated for generations by the descendents of immigrants. Much of the impulse behind environmentalism today can be attributed to this vision, and to its re-awakening in every new generation. Thoreau's pond was not a geographical frontier, and it lay close to a frontier of the mind, a metaphor for the human condition in its most elemental form, which continues to resonate today. ${ }^{28}$ 
The analysis of Thoreau's life (1817-1862) gives sense to the ecological dimension of the mythological frontier. Indeed, the very psycho-mental representation underlying the ecofrontier paradigm was greatly influenced by Thoreau's deep introspection in Walden in $1847 .{ }^{29} \mathrm{~A}$ character such as Thoreau is an instigator of a dense environmentalist pioneers' history. French 'romantic' philosophical thinkers (e.g., Rousseau [1717-1778] and Chateaubriand [1768-1848]), British demographist Malthus (1766-1834), German political environmental ideologues (Ratzel, 1844-1904), and other North American writers, such as Emerson (1803-1882) or painters, such as Cole (1801-1848), are examples of the key characters in the eighteenth and nineteenth centuries who participated in the creation of various political ideologies of nature. 'The sense of frontier is primarily about the effect of the interaction between human-made and wild nature on the cultural imaginary, the way that societies see themselves and others. ${ }^{30}[\ldots]$ Myths of nature surround us, but these myths serve to hide social and political realities, as well as to illuminate them. ${ }^{31}$ Nature as an indicator and a medium of instrumentation of socio-political dynamics is central to studying environmental conflicts. ${ }^{32}$ Indeed, if frontier dynamics are mainly related to material extraction (e.g., mining, forestry, fishing, and agricultural fronts), eco-frontiers seem more orientated towards immaterial appropriation (nature preservation, conservation, etc.).

Issues of boundaries are also important to this first generation of eco-frontiers. The development of modernity implied increasing control over the land and nature by centralised states, usually employing military means. These states established and enforced property regimes, which often challenged and transformed traditional rights to natural resources and helped secure a new relationship between central governments and civil societies. ${ }^{33}$ The processes of bounding and valuing nature and the land for the interests of the 'happy few' in the name of a so-called natural philosophy are central to eco-frontiers. These first boundaries ${ }^{34}$ were barriers and fences to enclose nature. Subsequently, land conflicts have been inherent in environmental conflicts. ${ }^{35}$ Outsiders mobilise territorialisation and networking processes to achieve their goals, and conflicting new territories and divided networking forces clash with land rights, land uses, and the ethnic identities of the local people. This tends to divide them into different categories, such as connected relays (of neo-colonisers), marginalised (and potentially virulent) citizens, ${ }^{36}$ or dominated masses. Eco-frontiers are consequently highly racialised, contested, and politicised zones of domination. ${ }^{37}$ To be appropriated, nature needs boundaries that serve, as well, to reserve zones of natural resources. Thus, ecological resources, seen as commodities, ${ }^{38}$ are also central to conflicts in eco-frontier establishments. 'The management of natural resources is intimately linked with wider histories of class conflict and market relations. [...] In the process of making frontiers, settlers often created what David Nye ${ }^{39}$ calls "foundation narratives", which brought them into conflict with indigenous groups and values. This is seen most vividly in the case of the USA, but also in Canada, Australia, and Afrikaner/British South Africa. ${ }^{40}$ If the protection of nature or other non-extractive ways of valuing ecological resources are understood as commodities and related to 'foundation narratives', which is often the case in mountainous pioneer societies such as in Bariloche (Argentina), eco-frontiers have a behaviour pattern very similar to frontiers. In this case, the difference between a 'classical commodity frontier' and an ecofrontier is linked to an opposition between purely non-renewable extractions versus renewable forms of ecological valuation.

This first generation of eco-frontiers is still active today and is integrated into the second and third generation. 


\section{Second generation: 'Geopolitical' eco-frontiers}

The second generation includes eco-frontiers that primarily serve the geopolitical interests of the States at different scales. Major conflicts have been the catalysts for using nature as a defensive tool. Although this second generation is considered to begin between the two World Wars, geopolitical and defensive use of nature started long before that. In the 1930s, there were many examples in Africa and South America of such processes - for example, along the Chilean/Argentinean border in northern Patagonia. ${ }^{41}$

The objectives pursued by the States are numerous: securing their borderlands ${ }^{42}$ while using nature as a nationalist symbol, ${ }^{43}$ state control of peripheral regions where local people have been removed from protected areas, and the use of Unesco Biosphere Reserves in some places to give new international legitimacy to border control. ${ }^{44}$ The main geographical/geopolitical concepts that clarify this second generation of eco-frontiers are the international border, at a national/international scale, and the buffer zone, at a local/regional scale. A simultaneous opposite process in this second generation is a strong opposition to this geopolitical/military use of the environment. This opposition developed with the post-1968 green "peacefication" movement that linked hippies and deep ecologists through the alternative values of rural return and organic life. This new green movement is clarified by the emergence of the third generation and determines most of the third generation's values and discourse.

How does this second generation of eco-frontiers relate to international borders and militarisation/defence objectives? It is interesting to examine the analogies between military conquest and eco-conquest. Literature on the subject shows how nature reservations are used for defence purposes ${ }^{45}$ and, alternatively, how military zones are today (re)converted into nature reserves. ${ }^{46} \mathrm{Kepe}^{47}$ elaborates on the analogy between a frontier war and an eco-conquest. He refers to Neumann, ${ }^{48}$ who 'argues that aggressive, and often violent, conservation policies in many parts of Africa and elsewhere, including the infamous shoot-on-sight orders for poachers in protected areas, are possibly indirectly motivated by the common language used in biodiversity conservation'. Neumann believes that 'the war metaphors, such as environmental security, environmental crisis, and war for biodiversity used to characterise environmental problems and solutions, have the effect of justifying and sanitising hard-line behaviour, mostly against the poor, in the name of conservation'. Following the same metaphoric logic, Kepe continues, '[S]ome self-confessed eco-centrists, such as Dave Foreman, drawing from Soulé and Wilcox, make a call to conservationists to "Defend strict protected areas as the most valuable weapon in our conservation arsenal". ${ }^{49}$ One can also refer to the connection between protected areas and military bases along the borders of South Africa (Ndumo Game Reserve, Mozambican border). Moreover, eco-frontiers are often used as geopolitical tools, serving military and strategic needs. ${ }^{50}$ In this context, it is not surprising that local South Africans are confused in their perceptions of the differences between army soldiers and conservation guards.

'Buffer zones' are an important and well-developed geographical/geopolitical concept regarding linking or separating nature from other spatial objects/subjects. Buffer zones serve to demarcate nature in service to a political project of the transition/exclusion of a certain region or a population, and they are also used as geopolitical reserves in the context of international border tensions. ${ }^{51}$ Following this logic, in Bolivia the Eduardo Avaroa National Reserve (Figure 2) was first proclaimed a buffer zone in 1974, during high diplomatic tensions with Chile and Argentina (Figure 2). ${ }^{52}$ Eduardo Avaroa was Bolivia's foremost hero of the War of the Pacific (which pitted Chile against Bolivia and Peru [1879-1883]) and was one of the leaders of 
the civilian resistance to the Chilean invasion at the Battle of Topáter. The history of Eduardo Avaroa gives even more sense to the proclamation of this national reserve. The Caprivi Game Park in Namibia also played the role of a 'buffer borderland' with respect to the surrounding African countries. Moreover, the 'paper parks' play an important role as buffer zones for the protection of international borders, mainly in Africa (see Giraut, Guyot, and Houssay-Holzschuch, ${ }^{53}$ ) and in South America (see Guyot and Amilhat-Szary). ${ }^{54}$ In 'paper parks', the map and related geopolitical discourses are the only evidence legitimising and legalising the existence of control over a piece of wilderness. This is the case with the Los Andes Provincial Nature Reserve in the Salta Province in Argentina: a large piece of nature, a green buffer zone, only conserved on the map, rarely 'environmentally patrolled' on the field, but which could be considered a 'geopolitical reserve' adjacent to the border of Chile in the context of a disputed international border (Figure 2).

Figure 2. Eco-frontiers of the 'triple frontera' region (ABC) in the Central Andes. Source: Author

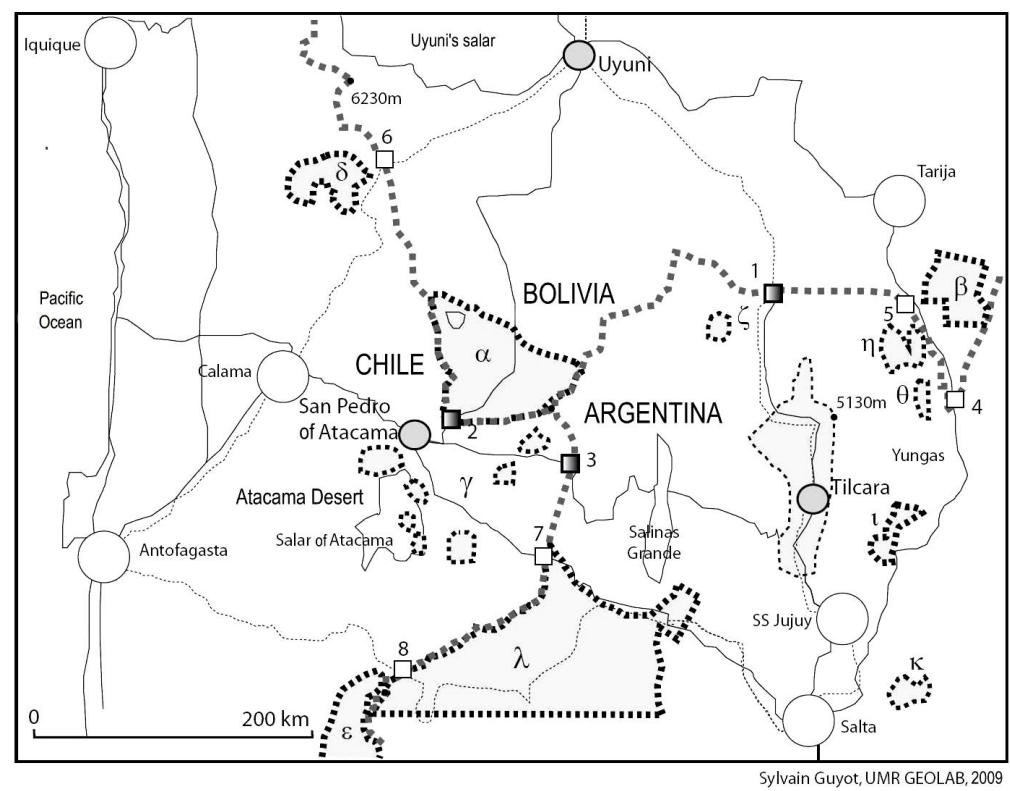

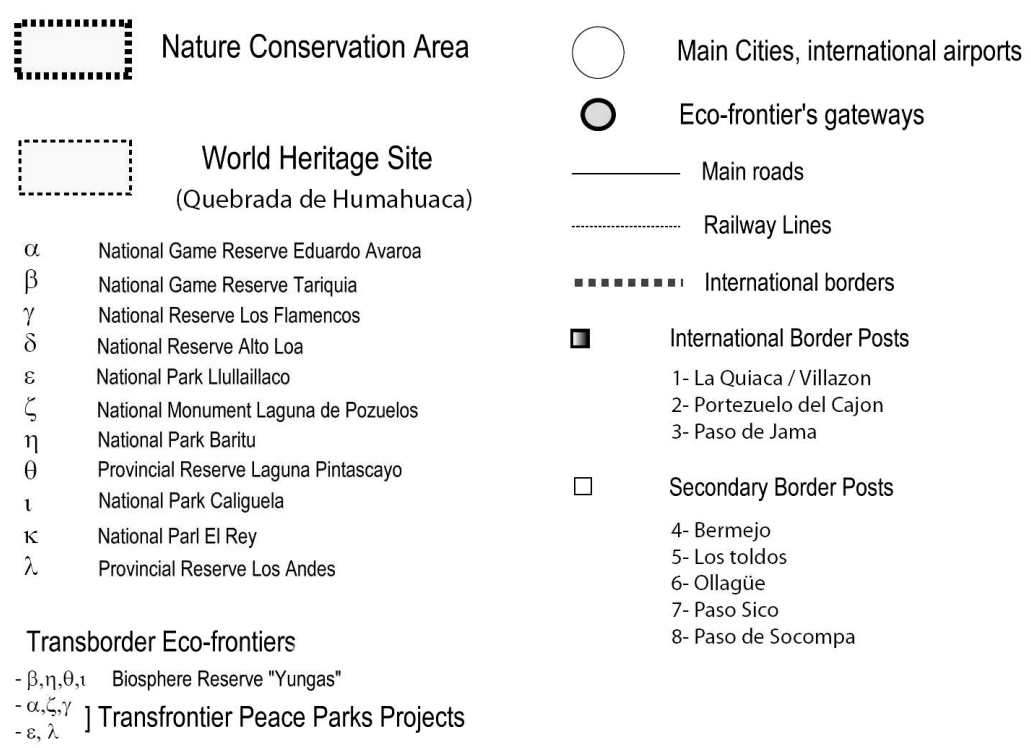




\section{Third generation: Global eco-frontiers}

Emerging processes that recycle and sometimes exaggerate the first and second generation's ideologies are at the heart of this third generation. Indeed, they work in parallel (and sometimes in association) with the dynamics of the first and second generations. First, the third generation of eco-frontiers is produced by actors on a global scale of intervention. Second, these actors produce discourses and representations in the name of the eco-frontier as an ecological/ecologist conquest. Third, the geo-economy of the eco-frontier is very powerful, and the eco-conquest works as a new economical appropriation of the world. ${ }^{55}$ This third generation shows the triumph of green thinking with an eco-recycling of everything, such as the diffusion of green washing. Four well-connected groups of actors produce different types of processes. The environmentalists map the world with new eco-frontiers with high biological value and cultural areas like biodiversity hotspots ${ }^{56}$ and indigenous reserves. ${ }^{57}$ They plead for the increase in size of protected areas all over the world, such as trans-border parks. ${ }^{58}$ The world organisations, like the World Bank and the UNEP, produce new ecofrontiers related to global change and emphasise the importance and value attached to ecological services. Some scientists and the media promote ultimate eco-frontiers as final barriers to world environmental destruction in the last secluded and remote areas of the world, such as Antarctica or isolated islands. Additionally, the general public contributes to the general 'ecologisation' of society by way of eco-tourism based on an eco-frontier dream. Thus, they contribute to the development of the concept of eco-conquerors. We will develop these aspects in the empirical study presented below.

The main geographical/geopolitical concepts supporting this third generation of eco-frontiers focus on the non-linearity of borders and on mobile borders. ${ }^{59}$ For instance, the transfrontier/trans-border protected areas linked to environmental networks that are supported by worldwide NGOs are central to this new geopolitical reality linking nature to space. ${ }^{60}$ However, the South African example ${ }^{61}$ makes it clear that such notions still serve State security or Empire-style territorial hegemony and refer to the first and second generations of eco-frontiers. In Southern Africa, protected areas serve many diverse interests, such as nature conservation, racial segregation, and elitist hedonism. These motivations can be ambiguous and contradictory. Transfrontier parks have the capacity to be used as geopolitical tools at a supranational scale. During the apartheid era, South African border parks were buffer zones for Mozambican and Angolan civil wars. Currently, these protected areas have been relegitimised by official discourses on peace and by environmental and tourist cooperation between South African States: the concept of Transfrontier Peace Parks (TPP). TPP are a method for politico-economic domination, rather than a social redistribution tool. They thrust a proto-colonial discourse into the post-colonial era of global capitalism. The TPP could be legitimised by real diplomatic actions in favour of democracy in the bordering countries or by a real political integration at a regional level. However, the TPP do not resolve the issues of illegal immigrants, evidence that denying boundaries also benefits black people, and serious developmental gaps between South Africa and most of its neighbours. Colonial conservation, through its European imaginings of wild nature and avoidance of the technical and aesthetic sensibilities of black Africans, has allowed for the creation of a vast system of South African national parks and the disenfranchisement of indigenous populations. Conservation and natural-resource management were two sides of the same coin, and they produced similar effects of (a) the ordering and (b) the othering of the "black African". Through a moral and economic visionary discourse masked in technical and scientific terminology, colonial conservation furthered the othering of Africans from their lands and resources. It also created opportunities for territorial claim staking by the postcolonial state and international 
stakeholders. A neo-liberal market ideology, combined with romantic 'dreams' of 'tourism nature parks', has allowed South African political and economic actors to recolonise southern Africa through TPPs. (In this context, supplementary notions of environmental racism $^{62}$ and environmental justice ${ }^{63}$ may be useful, but these will not be developed here.) This example shows precisely how the three generations of eco-frontiers can be combined within one territorial geopolitical strategy.

The next two parts of the paper empirically and theoretically develop the contents of the third generation to illustrate the current constructed discourse on eco-frontiers and the new strategies of green territorial domination.

\title{
The making of global eco-frontiers by environmentalists
}

\begin{abstract}
The new dimensions of green geopolitics are not innocent constructions of the environment. They signify a particular understanding of the world which relates closely to the traditional thinking of global geopolitics, but which has now been revived and reformulated in terms of a new language. This language is a strategy for conceptualising, thematising, and even controlling nature. Consequently, ecology emerges as a geopolitical metaphor, whereas wild nature becomes a passive ecosystem infrastructure, simply waiting to be tamed by green geopolitics. ${ }^{64}$ Eco-systemic structures are, in other words, related to political power entrapped within the global political economy. This form of geopolitics is described by an Indian scholar, Vandana Shiva, as Green Imperialism. ${ }^{65}$
\end{abstract}

The discourse on eco-frontiers was initially created by various stakeholders to publicise, justify, and even put into practice a set of ideologies and representations of nature. ${ }^{66}$ This discourse is based on a specific vocabulary and is a preliminary to the formulation of any territorial strategy of domination. A first methodological point concerns the context of creation and the extraction of this discourse, while a second point elaborates on the specific representations and ideologies of nature underlying these contemporary eco-frontiers.

\section{Methodology: how is the eco-frontier discourse created and by whom?}

The imaginary regarding eco-frontiers relates to a colourful imagery of notions, such as wilderness, immensity, remoteness, unlimited spaces, scarce or abundant nature, idiosyncratic local populations, etc. Even in the industrial sphere, the eco-frontier is synonymous with the cleanliness and perfection of a steel product. ${ }^{67}$ These notions are connected to particular inventions, ideologies, representations and political instrumentations of nature. In fact, the cultural construction of eco-frontiers directly emanates from green stakeholders. Evidence for eco-frontiers is found in the words used and in practices done in the name of these words. The eco-frontier vocabulary comprises a set of neologisms, mostly created contemporarily by environmentalists and 'committed' researchers.

The most common neologisms created around eco-frontier(s) are conservation frontier, ecosettlers, eco-conquerors, and eco-warriors. They were found and researched mainly on the web to determine which organisation uses which term(s). ${ }^{68}$ Occurrences of these words are not yet very numerous; this paper focuses on the emerging characteristics of this vocabulary. Websites were chosen according to the neologisms referenced, with sufficiently explicit use to make sense of and clarify stakeholders' positions. The vast majority of these websites arose from green stakeholders, i.e., actors invested in environmental fields from different perspectives. Next, a selection was made from all the web pages reviewed, assessing the economical, political, ideological, and spatial dimensions of their discourses and practices. 
Table 2 shows examples of twelve selected stakeholders using one or more of these neologisms. These actors were classified by alphabetic rank. The positioning of each stakeholder was decrypted according to various factors for analysing how these neologisms were used: identity, country, space and place of actions, scale, networks, acknowledged or 'supposed definition', associated norms, interpreted utilisation and instrumentation, representations of nature (psycho-mental and spatial), and collateral conflicts.

\section{[Table 2 about here]}

Four main categories of stakeholders emerge from a synthetic reading of Table 2 . The first group of actors using an eco-frontier lexicon are eco-tourism operators. Here one needs to distinguish between 'general' tour operators linked to the 'large consumption' of eco-frontiers (as in Thailand or Africa) and more individualised operators advocating a return-to-nature approach (e.g., Eco-frontiers Ranch in Poland or Grishino Ecological Village in Russia). The second and main group of actors referring to 'eco-frontiers' and other neologisms are the socalled 'environmentalists': foundations, NGOs, and associations emanating from civil society and working directly or indirectly for the protection of nature (e.g., Dancing Star Foundation or Earth Future). The third group of actors showing a link with eco-frontiers are research centres and universities justifying future investment in research informed by these neologisms (e.g., the Eco-frontier Fellowship Program or the Ecological restoration group. ${ }^{69}$ Finally, the fourth main group includes geo-economic diverging groups referring directly to eco-frontiers as a way to market green industrial solutions, like the Eco-frontier LTD Company. This study asked the following question: What specific representations and ideologies of nature underlie the creation of an eco-frontier discourse by these selected actors?

\section{Eco-frontiers: specific representations and ideologies of nature}

The 'Dancing Star Foundation' and 'Earth Future' connect themselves to a radical movement of preservation based on the strict protection of animal rights (an eco-centric approach ${ }^{70}$ ). Both the 'written' vision of the Dancing Star Foundation ${ }^{71}$ and pictures (Figure 3) extracted from its website show the equal treatment of animals and indigenous people (especially children). Vegetarianism and the sanctuarisation of nature also add to this representation of childish nature, surely concealing other more radical claims, such as 'deep demography': 'Deep demography is about grappling with the population and ecological demons we have unleashed in a forthright manner. [...] there is no vacancy on planet Earth, not for humans anyway'. ${ }^{72}$ Their representation of the eco-frontier is viewed as a restricted territory reserved for only a few humans with the 'right way of life', although the outreach of their message is supposedly universal. In their message, they including content belonging to both the first and second generations of eco-frontiers described above. 
Figure 3. Eco-centric representations from the Dancing Star Foundation. Source: http://www.dancingstarfoundation.org/photos.php, accessed 13 May 2009.

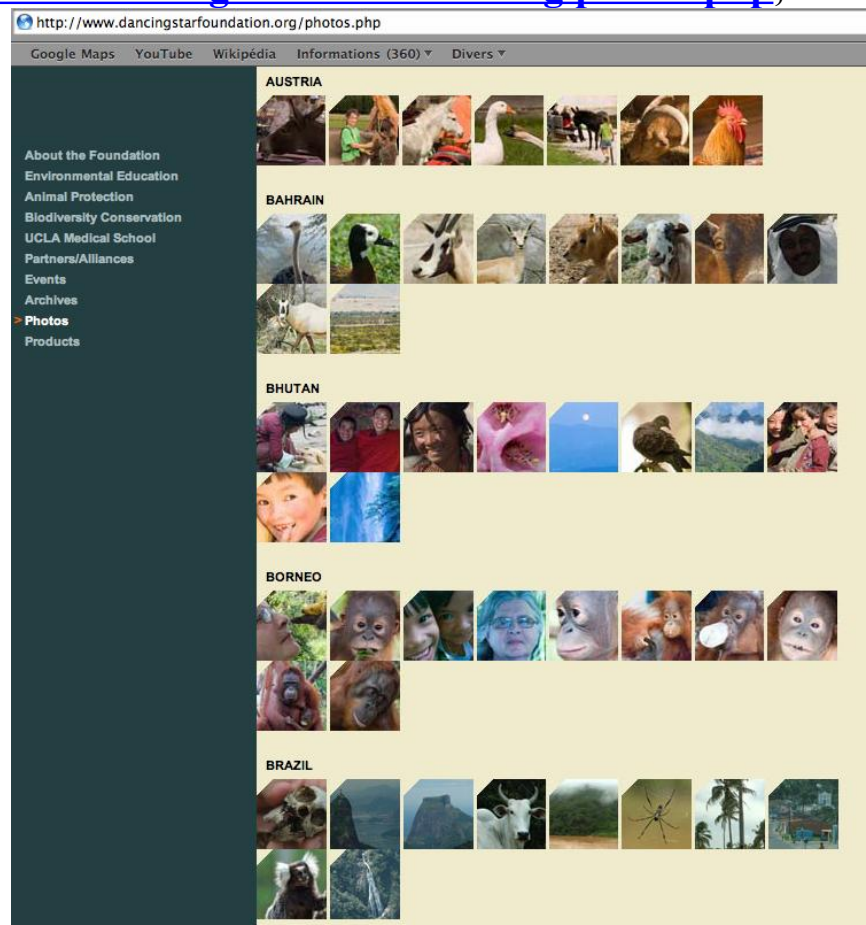

'Eco-frontiers Ranch' and 'Grishino Ecological Village' (GEV) belong to another type of preservation, much closer to Thoreau's perspective, ${ }^{73}$ based on a 'more-or-less collective' return-to-nature philosophy. The document below, extracted from the GEV website (Figure 4), explains the psycho-mental representation underlying the vision of these eco-settlers: a mix of 'hatred of the city', 'come back to tradition', 'struggle against forest devastation', and 'find spiritual connection with nature'. Their message of outreach remains focused at the local scale, even while this particular eco-village is connected to a network of other Russian ecovillages. The Eco-frontier Ranch is more of a private business, driven by ecologists attempting to share their experimentation of the eco-frontier life in a remote borderland. Their philosophy directly refers to the romantic side of the first generation of eco-frontiers. 
Figure 4. Eco-frontier representation in a Russian ecological village.

Source: http://www.grishino.ecology.net.ru/en/index.htm, accessed 13 May 2009.

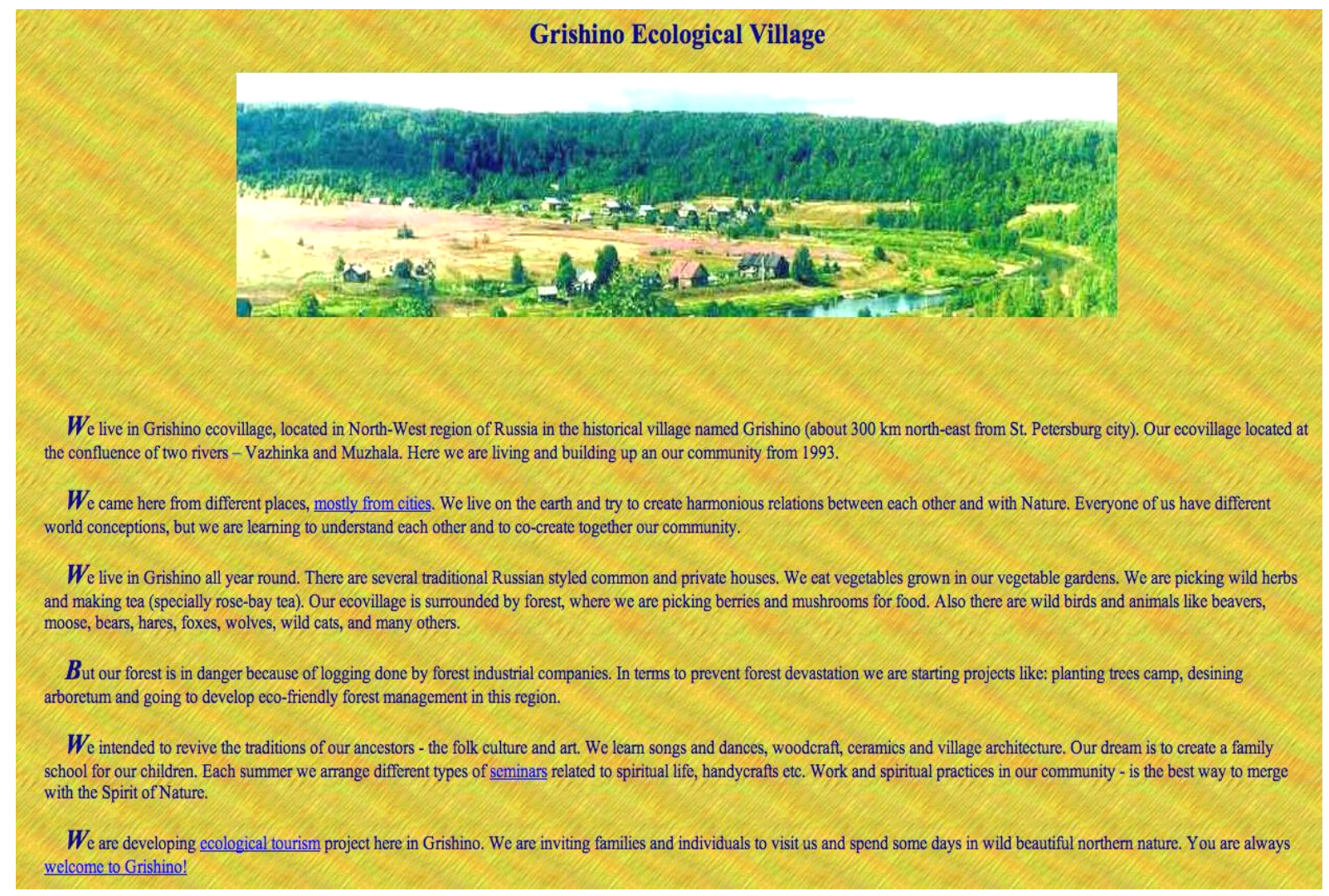

'Circle of Asia' and the eco-tourists from the WAYN (Where Are You Now?) website both highlight a form of hedonism, very common today among 'environmentally friendly travellers' and well underlined by the French philosopher M. Onfray. ${ }^{74}$ This representation of the eco-frontier is of a remote aesthetical paradise that meets the need for escape from routine urban life. This is perfectly illustrated with the beautiful beach (Figures 5 and 6; located at Ko Phi Phi Lee, Krabi Province, Thailand), where mapping is an invitation to discover 'ecofrontier paradises' - for example, as shown in the story of the 'famous map of the mystery island' in the novel The Beach by Alex Garland (1996), represented in the movie (2000) directed by D. Boyle with L. DiCaprio. The processes occurring on this island during and after the making of the movie are intimately related to our topic. ${ }^{75}$ 
Figure 5. Tool of eco-frontier conquest: "The Beach Map".

Source: http://travel.webshots.com/photo/1026067364015760230wJFyzgCqws, accessed 13 May 2009.

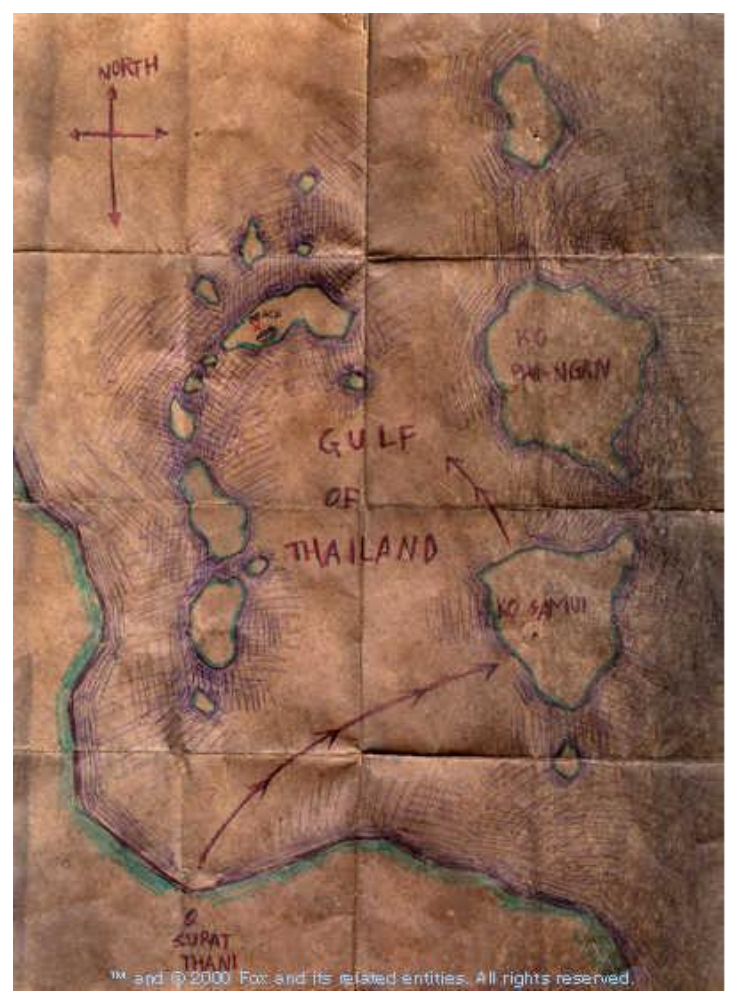

Figure 6. The Beach, a paradisiacal eco-frontier?

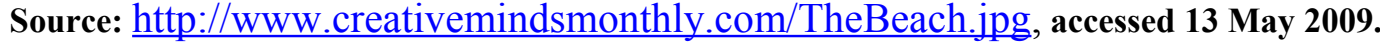

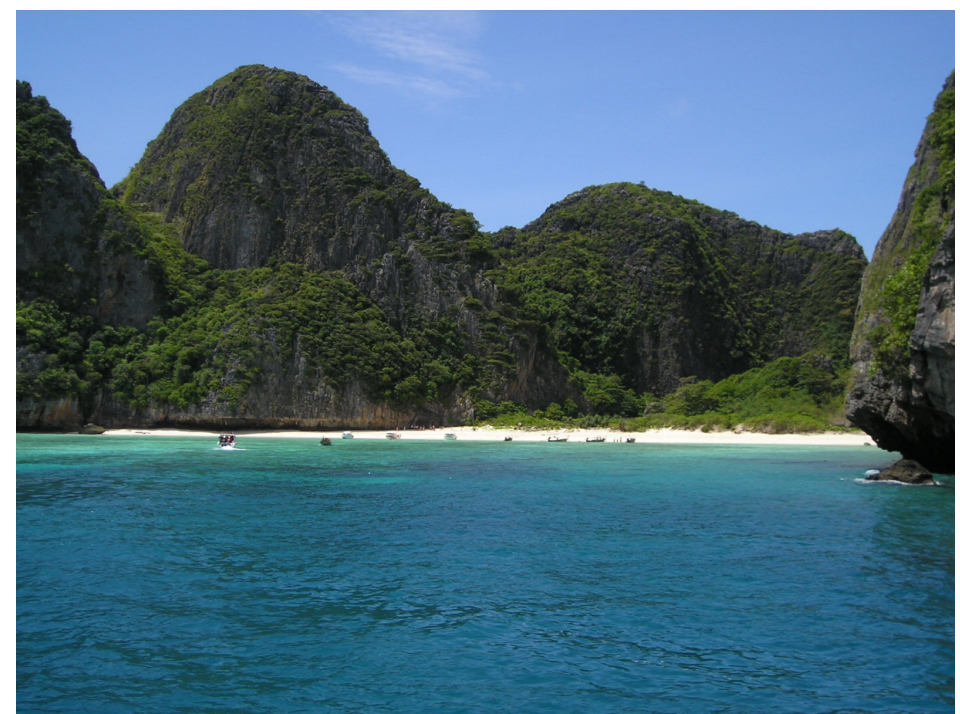

Far away from Leonardo DiCaprio, the 'Biosphere 2' project is associated with the Gaïa theory, ${ }^{76}$ in a more artificial and confined version. It can be viewed as a sort of 'eco-frontier laboratory', a very risky experiment that has actually failed. On the real land side, 'The Land is Ours' is a typical environmental justice organisation. Its representation of the eco-frontier involves better access to land for eco-settlers wishing to promote ecologically friendly agriculture. Finally, the Fairfax County Federation of Citizen Associations (FCFCA) is 
connected to nature conservation through a community-participation perspective grounded in a regional natural park in the state of Virginia, in the United States.

Conservation has transcended the "freeze in the dark" connotations of the 1970s and is becoming a vibrant and foundational part of our everyday lives! To further this exciting trend, join the "Community Conservation Conversation", featuring discussion among panel members and the audience. The key to a better and less consumptive society and economy is opening up the floodgates of conversation on this very important topic. A number of area conservation initiatives will be highlighted. ${ }^{77}$

The representation of their 'conservation frontier' is orientated towards a smooth inclusion of local communities. Thus, they acknowledge the major shift realised worldwide in conservation practices. Not all representations of conservation frontiers necessarily include these 'integrative' aspects, as in the Wild Coast example in South Africa. ${ }^{78}$ First and second generations of eco-frontiers are superimposed over the conceptions of these various green actors.

Finally, the Eco-frontier LTD company shows a more geo-economic representation of the eco-frontier. Eco-frontier LTD was established in 1995 to contribute to achieving global sustainable development by incorporating social and environmental value into economic value. They currently develop a Biomass CHP CDM Project in Malaysia. The idea is that produced steam is supplied to palm oil refineries and bio-diesel factories, and the electricity is sold to the regional utility, Sabah Electricity Sdn. The eco-frontier is seen as a new space of development for green industrial markets. This can be seen as an intrinsic characteristic of the third generation of eco-frontiers: the green economy is typical of the contemporary era.

\section{Figure 7: The Biomass CHP CDM Project in Malaysia}

Source: http://www.ecofrontier.com/eng/business/reference.asp, accessed 23 June 2010.

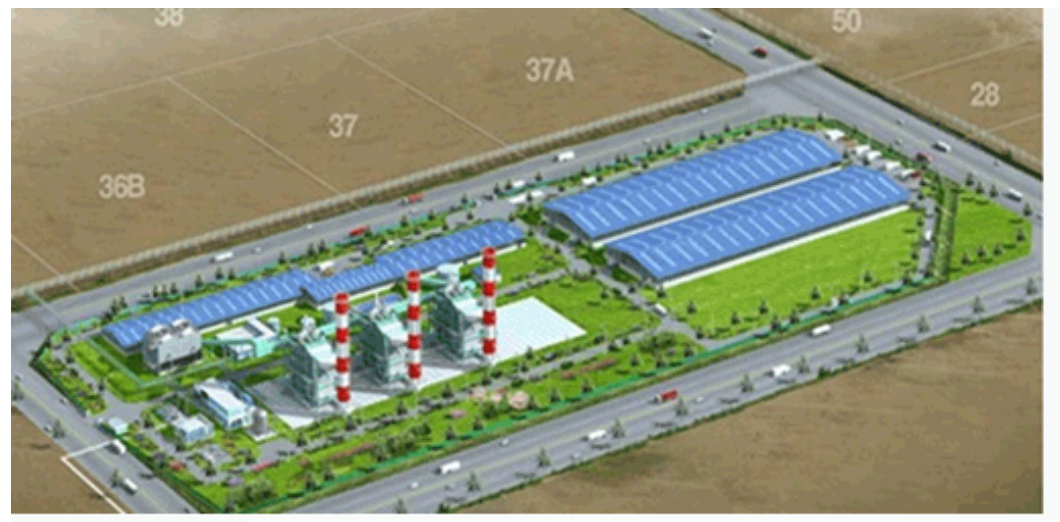

POIC CHP Project Sabah, Malaysia

All of these discourses and representations that underlie specific premises of eco-frontiers are aimed at inducing some forms of territorial domination orchestrated by different types of ecoconquerors. Who are they, and for what strategies of domination are they being used? 


\section{Eco-conquerors and territorial domination}

Spatial representations associated with eco-frontiers are founded on two major visions. Both visions highlight the desire to conquer new frontiers of nature. Thus, the first vision is an ecoconquest linked alternatively to an exclusive community oxymoron: imprisonment versus enjoyment. The second vision refers to an individual Malthusian paradox (individual isolation for pleasure) of the 'lost paradise'. Both visions convey restrictive conditions to create inclusive and democratic territories. Each of these constructed views of nature provides information about the actor(s) who created or formulated these representations. Thus, actors having evident or latent desires or claims on eco-frontiers will be called 'eco-conquerors'. They are the driving forces of global eco-frontiers, although their profiles and forms of actions are diverse; these depend largely on their eco-political affinities and ideologies.

\section{Eco-conquerors and the domination of global eco-frontiers}

This attempt to objectivise the profiles of eco-conquerors is important for formalising neologisms that could be used as a common basis for scientific referencing. As a methodology for this typology, we selected four main criteria to differentiate eco-conquerors' profiles in their quests of eco-frontiers. These criteria were based on empirical knowledge developed in some exemplary fields of various eco-conquests around the world. ${ }^{79}$ The first criterion attempts to distinguish the distinct temporalities of ecological appropriations: virtual, distant and temporary, or temporary and permanent. The second criterion defines the profile of the stakeholder: world organisation, environmental NGO, individual, company, state, administration, tour operator, church, etc. The third criterion looks at the types of appropriation. These can be diverse: vacation, residential, nature conservation, business, spirituality, leisure, activism, terrorism, etc. The last criterion analyses contrasting reactions from local people: compromise, economical acceptance, rejection, etc. According to these four criteria, and in correlation with the previously described political ideologies of nature, a dozen profiles can be highlighted (see Box 1 below). 


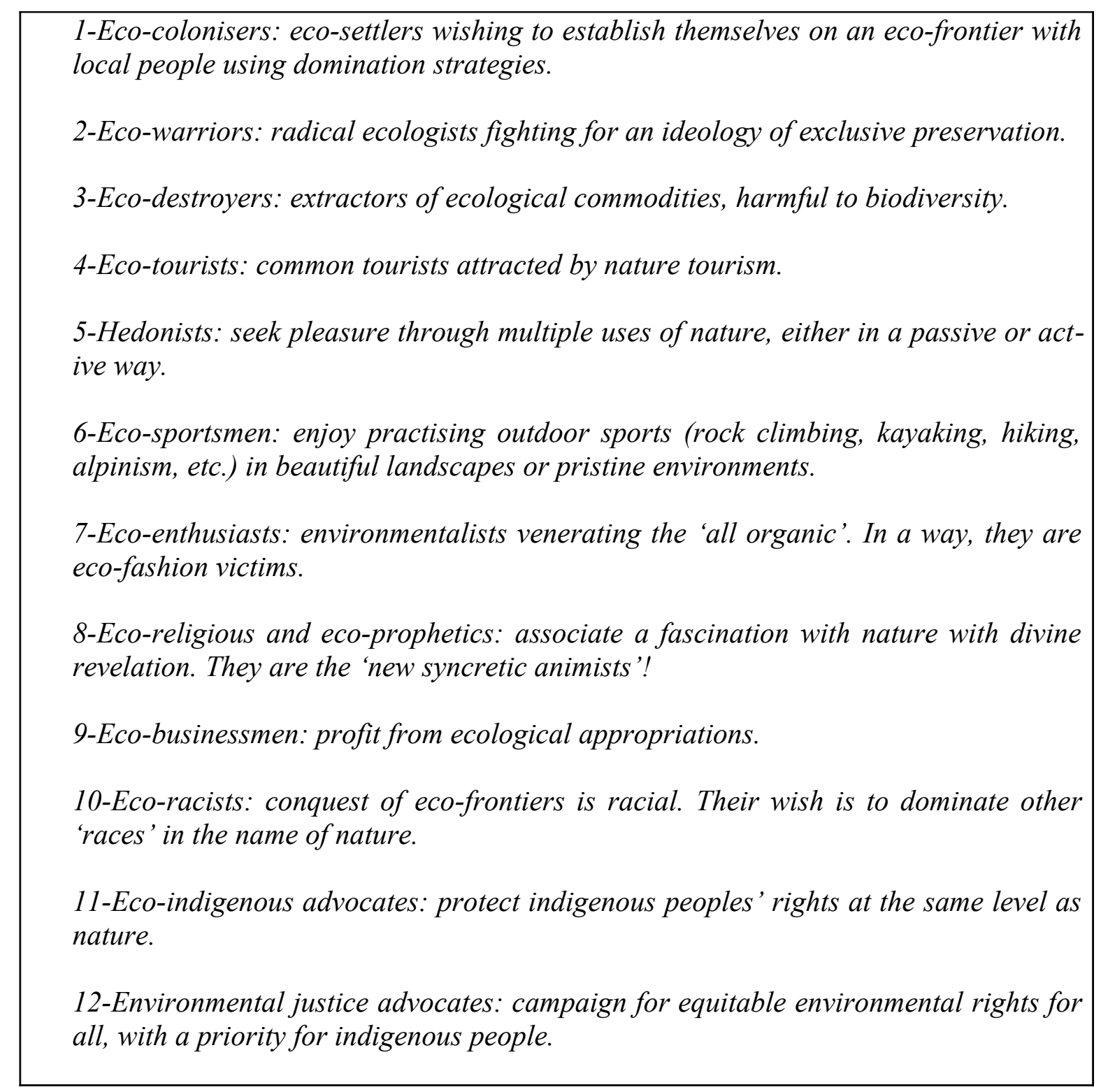

Box 1. Twelve profiles of eco-conquerors of nature.

All of these eco-conquerors have their own spatial representations of eco-frontiers. Some of them locate and practice these in remote and exotic countries, others on their own doorsteps, and others on their screens (internet, television, cinema, etc.). Each category rallies a specific form of territorial domination.

The basic forms of territorial domination in the name of eco-frontiers lie in three modes of appropriation: first, a final and exclusive appropriation of eco-frontiers, brutal to local people; second, a temporary and nomadic appropriation of eco-frontiers, confrontational to local people; and, third, a distant and virtual appropriation. Eco-colonisers, eco-warriors, and ecodestroyers generally practice the first mode of appropriation, as highlighted in many South African areas. ${ }^{80}$ Eco-tourists, hedonists, and eco-sportsmen belong to the second form of appropriation. Examples of this green hedonist imperialism are very common worldwide. ${ }^{81}$ Finally, eco-enthusiasts and the eco-religious are mostly included in the third type of appropriation, as stressed by many eco-websites. Other eco-conquerors defined in Box 1 divide themselves among these three forms of appropriation. These categories can be linked to the examples of environmentalists described previously (Table 2). Thus, territorial 
domination in the name of nature and ecology pave the way for new forms of green (global) geopolitics.

\section{New green geopolitics?}

'Green geopolitics' ${ }^{82}$, or emerging eco-politics, ${ }^{83}$ here refers to discourses, strategies, and actions adopted by various groups of stakeholders wishing to influence or initiate (new forms of) environmental politics at various scales in diverse geographical areas. Subsequently, the uses of the eco-frontier paradigm and neologisms derived by these organisations imply territorial projects and perspectives located in strategic areas. How are these geopolitical discourses and actions geographically grounded (through space and scale), and do they operate through specific networks? What are the different geopolitical claims originating from these green stakeholders?

Table 2 shows that these environmentalists locate 'their' eco-frontiers mainly in rural areas or peripheries of the first world (Eastern Europe, especially: Poland and Russia, rural England, or the United States) or of the third world (Thailand or Africa). 'Spatial priority' is given to borderlands (the border between Poland and Ukraine), mountain ranges (Poland, Virginia, and Switzerland), coastal areas (Thailand, Canada and Korea), and deserts. In the example of Biosphere 2, eco-frontiers are not precisely located and can represent any area on the Earth, forcibly contained and bounded in a small dome. Scales of spatial inscription and action differ from global to either local, regional, or national. This means that the will to legitimise and/or to fight for an eco-frontier is diversely organised. Some organisations have more global powers than others; networking follows exactly the same logic. This gives an indication of the global level of the eco-frontier paradigm and its associated neologisms. The word 'ecofrontier' seems quite international and is sometimes used as a branding tool, even to promote so-called sustainable industrial solutions. What credible geopolitical claims and domination strategies emerge from these stakeholders?

Comparative readings of Table 2 can reveal a great deal about the geopolitical spirit espoused by these stakeholders. One main idea is shared by most of the organisations: the desire to go beyond the limits of space, knowledge and innovation. Three strategies of domination of the 'unexplored' and of the 'unknown' emerge. First, the appropriation by eco-conquerors of a eco-front (recognised for its exceptional nature) is done to preserve or conserve its ecological assets (Eco-frontier Ranch, Circle of Asia, Grishino Ecological Village, etc.). It is a de facto territorial domination. In the case of the Eco-frontier Ranch, some eco-colonisers try to attract eco-tourists, eco-sportsmen, and eco-enthusiasts to enjoy a return to the natural rural way of life of the pre-collectivisation era. In the case of Grishino Ecological Village, a mix of ecocolonisers and eco-religious intend to occupy an area to prevent it from being destroyed by foresters. Second, the domination is realised through intellectual or technological doctrines. Territorial appropriation is mainly accomplished on a virtual level, although also by influencing some field practices. Eco-warriors formulate the adoption of new themes and methods for ecological political activism (Dancing Star Foundation and Earth Future). Other examples have shown attempts from competitive environmental currents to influence the debate, like eco-indigenous advocates $\left(\right.$ Survival $^{84}$ ) or environmental justice activists (Environmental Justice Networking Forum, ${ }^{85}$ South Africa). Third, domination can be seen through the necessity of conducting new environmental academic research favouring international cooperation (such as the Eco-frontier Fellowship) or developing green industrial processes (Eco-frontier LTD Company). 
The first logic described appears to be locally scaled. Nevertheless, such claims for ecofrontiers may have social and economic impacts that can influence regional politics with sometimes unexpected consequences at a higher political level, especially when the ecofrontier is located in a borderland (see Box 1). The second and third logics have perhaps more influence on global geopolitics, especially if they are linked to well-structured international networks, as with the Dancing Star Foundation or Earth Future. Radical preservationism (and its 'eco-warriors') is often linked to so-called 'eco-terrorism', apparently a seriously perceived geopolitical threat for the American populace ${ }^{86}$ and some of its authorities.

Finally, analysed in a more general context, all of the political discourses carried out by these eco-conquerors tend to legitimise strict ways of life and new territorial identities. First, vegetarianism and respect for animal rights both refer to a radical transformation of human practices on Earth. Second, the use of 'connoted' place names, like the 'Eco-frontier Ranch', in a country with mainly slavish place names refers to a form of eco-globalisation of local identities. Third, territorial branding, as in the 'Wild Kingdom of Thailand', refers to a political marketing ploy to market a country based on its wild imagery. All of these views on global eco-frontiers do not imply a structured and unified geopolitical project, but are a combination of local/regional strategies, international principles and new environmental doctrines. Incidentally, the eco-frontier discourse is not used yet to consolidate international norms with regard to legal theory. In reality, domination through and across eco-frontiers is accomplished according to two main actions: eco-conquest (with environmental, land and economic appropriation objectives) and environmental activism. The ecological frontier then becomes the global environmentalist frontier, a sort of digest of its three generations, where economic interests and territorial appropriations by the actors count much more than the strict protection of the ecosystems.

\section{Conclusion}

The eco-frontier is a paradigm for thinking globally about the links between space, nature and politics in integrating evolving geographical/geopolitical concepts at different times and influenced by different types of ideologies. Eco-frontiers imply a genealogical understanding of the conquest of nature by humans, where the filiation between the different generations is consistent. Therefore, the first generation of 'Imperial eco-frontiers' and the second generation of 'Geopolitical eco-frontiers' are still active within the third generation of 'Global eco-frontiers'. In reality, the discourse on eco-frontiers has been generated contemporarily, and it is used as a paradigm to inform modern processes of nature protection. Eco-frontiers allow a dialog between researchers and environmentalists, and they create space for critics and distance in the relations between space and nature. Moreover, eco-frontiers add new perspectives to the emerging field of eco-politics or green geopolitics. Indeed, the social, political, and environmental problematics of eco-frontiers are complex and add ecological imaginings, discourses, and actions to the classical competition over natural resources and labour. In fact, since the creation and genesis of the word 'eco-frontier' by 'green stakeholders', it has been used as a subliminal, bottom-up geopolitical tool. For instance, appropriations by eco-conquerors in a pioneer front recognised for its exceptional nature are done to preserve or conserve its ecological assets. This conquest is reserved for 'ecologically compatible' clients who also claim a specific eco-identity in the (sometimes virtually) settled territory. Moreover, the adoption of new themes and methods for ecological political activism is done in the name of eco-frontiers. Thus, all the representations and ideologies of nature discussed in this paper can produce specific typologies of 'eco-conquerors' linked with 
various forms of eco-frontier appropriations. The final and exclusive appropriation of ecofrontiers leads to confrontational geopolitics, especially within border territories. Temporary and nomadic appropriation of eco-frontiers is unstable and is a form of geopolitical instrumentalisation done mainly by corporate stakeholders. Distant and virtual appropriation is representative of 'web geopolitics'. In that sense, the Internet can be seen as a tool for the eco-geopolitical conquest of the world.

Thus, the paradigm of the eco-frontier is a way to understand the geopolitics of contemporary land appropriation throughout the world by environmentalist action and discourse. Ecofrontiers increase the status of natural spaces as expressions of geopolitical conflicts. 
${ }^{1} \mathrm{http}: / /$ www.airies.or.jp/ecofrontier/index E.html accessed 11/05/2009.

2 http://fr.wikipedia.org/wiki/Biosph\%C3\%A8re II accessed 11/05/2009.

${ }^{3}$ W.J. Broad, "Paradise Lost: Biosphere Retooled as Atmospheric Nightmare [archive] », 19 novembre 1996, The New York Times accessed 11/05/2009.

${ }^{4}$ http://www.booz.com/global/home/what we think/reports and white papers/article/40154486accessed 11/05/2009.

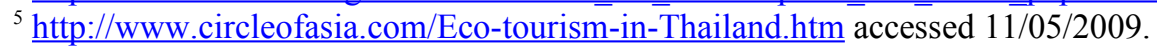

${ }^{6} \mathrm{http}: / /$ www.earthfuture.com/ accessed 11/05/2009.

7 http://www.ecofrontier.com/eng/company/overview.asp, accessed 23/06/2010.

${ }^{8}$ http://www.ecofrontiers.net accessed 11/05/2009.

${ }_{9}$ http://www.eco-tips.net/octoberecofrontier; http://www.dancingstarfoundation.org accessed 11/05/2009.

${ }^{10} \mathrm{http}: /$ www.wayn.com/waynphotos.html?wci=photo\&photo key=22769892\# accessed 11/05/2009.

${ }_{11} \mathrm{http} / /$ www.fairfaxfederation.org/bulletin/FCFCAbulletin0709.pdf accessed 11/05/2009.

12 http://www.grishino.ecology.net.ru/en/index.htm accessed 11/05/2009.

${ }_{13}^{13} \mathrm{http}: / /$ www.tlio.org.uk accessed 11/05/2009.

14. Juliet J. Fall, Artificial states? On the enduring geographical myth of natural borders, Political Geography 29 (2010)

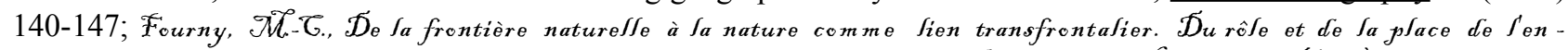
vironnement et du mifieu dans fes coopérations transfrontafières. In G. Douquet, \& \#. Fefasco (Eds.). 政opisme des

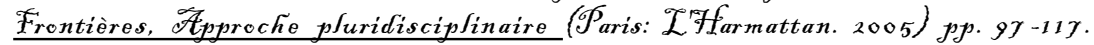

${ }^{15}$. See World Resources Institute, http://www.wri.org/, accessed 21 June 2010.

${ }^{16}$. See http://www.wri.org/about/donors, accessed 21 June 2010.

${ }^{17}$. D. Bryant et al., The Last Frontier Forests: Ecosystems And Economies On The Edge, What Is The Status Of The World's Remaining Large, Natural Forest Ecosystems? (Washington: World Resources Institute 1997)

${ }^{18}$. Ibid, p.6.

${ }^{19}$. Ibid, p.8.

${ }^{20}$. Definition in http://www.thefreedictionary.com/wilderness, accessed 22 June 2010.

${ }^{21}$. Definition, IUCN, see http://encyclopedia.thefreedictionary.com/protected+area, accessed 22 June 2010.

22. S. Guyot, Fronts écologiques et éco-conquérants : définitions et typologies. L'exemple des «ONG environnementales en quête de Côte Sauvage (Afrique du Sud)», Cybergeo article 471 (2009) on line URL: http://www.cybergeo.eu/index22651.html; S. Guyot, F. Richard., Les fronts écologiques, une clef de lecture socioterritoriale des enjeux environnementaux ?, Espace Politique, introduction to the themed issue 9 (2009) on line URL: http://espacepolitique.revues.org/index1422.html; S. Guyot., J. Dellier (eds.), Rethinking the Wild Coast (South Africa): eco-frontiers versus livelihoods in Pondoland (Saarbrücken: VDM Verlag 2009).

${ }^{23}$. M. Redclift, Frontiers, histories of civil society and nature (London: MIT Press 2006) pp. viii.

${ }^{24}$. W. Beinart, L. Hughes, Environment and Empire (Oxford: Oxford University Press 2007).

${ }^{25}$. T. Griffiths, L. Robin, Ecology and Empire: environmental history of settler societies (Pietermaritzburg, University of Natal Press 1997).

${ }^{26}$. C. Lloyd, Australian and American Settler Capitalism: The Importance of a Comparison and its Curious Neglect, Australian Economic History Review 38/3 (1998) pp.280-305.

27 . D. G. Payne, Voices in the Wilderness, American Nature Writing and Environmental Politics (London: University Press of New England 1996); Y. Figueiredo, Aux sources du débat écologique contemporain : l'expérience américaine, Revue française d'études américaines 109 (2006) pp. 69-82.

${ }^{28}$. Redclift (note 10) p.4.

${ }^{29}$. L. Buell, The Environmental Imagination: Thoreau, Nature Writing, and the Formation of American Culture (Cambridge, MA: Harvard University Press 1995)

${ }^{30}$. Redclift (note 10) p. 41.

${ }^{31}$. Redclift (note 10) p. 44; G. Waitt, L. Head, Postcards and frontier mythologies: sustaining views of the Kimberley as timeless, Environment and Planning D 20 (2002) pp. 319-344.

${ }^{32}$. Guyot (note 9).

${ }^{33}$. Redclift (note 10) pp. 29-31.

${ }^{34}$. E. Semple, Geographical boundaries, Bulletin, American Geographical Society, 39 (1907) pp 385-397; 449-463.

${ }^{35}$. S. Guyot, Zulu Shores, Green Disputes in Black and White (Saarbrücken: VDM Verlag, 2008); Guyot and Dellier (note 9).

${ }^{36}$. R. Neumann, Imposing Wilderness: Struggles over Livehood and Nature Preservation in Africa (Berkeley: University of California Press 1998).

${ }^{37}$. D. White, Hierarchy domination nature: Considering Bookchin's Critical Social Theory, Organization and Environment 16/1 (2003) pp 34-64.

${ }^{38}$. N. Castree, Commodifying what nature?, Progress in human geography $27 / 3$ (2003) pp. 273-297.

${ }^{39}$. D. Nye, America as Second Creation: Technology and Narratives of New Beginnings (Cambridge: MIT Press 2003)

${ }^{40}$. Redclift (note 10) p. 34.

${ }^{41}$. R. Miniconi, S. Guyot, Conflicts and cooperation in the mountainous Mapuche territory (Argentina), Journal of Mountain Research 98/1 (2010) on line, URL : $\underline{\text { http://rga.revues.org/index1151.html }}$ 
42. C. Ferradas, Environment, Security, and Terrorism in the Trinational Frontier of the Southern Cone, Identities: Global Studies in Culture and Power 11 (2004) pp. 417-442.

${ }^{43}$. T. Mels, Nature, home, and scenery : the official spatialities of Swedish national parks, Environment and Planning D: Society and Space 20 (2002) pp. 135-154.

44. S. Guyot et al., Acteurs et territorialisations conflictuelles autour de la «mise en réserve » de l'Alto Bermejo (Argentine-Bolivie), Géocarrefour 82/4 (2007) pp. 255-263.

45. A.H. Westing, Protected Natural Areas and the Military, Environmental Conservation 19 (1992) pp. 343-348; S.

Ellis., Of elephants and men : politics and nature conservation in South Africa, Journal of Southern African Studies 20/1 (1994) pp. 53-69.

46. D.G. Havlick, Logics of Change for Military-to-Wildlife Conversions in the United States, GeoJournal 69 (2007) pp. 151-164; J.S. Davis et al., Military pollution and natural purity: seeing nature and knowing contamination in Vieques, Puerto Rico, Geojournal 69/3 (2007) pp. 165-179.

${ }^{47}$. See the paper in this themed issue.

48. R. Neumann, Moral and Discursive Geographies in the War for Biodiversity in Africa, Political Geography 23/7 (2004) pp.816-817.

49. D. Foreman, Take back conservation movement, International Journal of Wilderness 12/4 (2006) pp. 4-31.

50. Ellis (note 32).

${ }^{51}$. N.S. Paudel et al., Buffer Zones: New Frontiers for Participatory Conservation?, Journal of Forest and Livelihood 6/2 (September 2007) pp 44-53; D. Correll, Principles of planning and establishment of buffer zones, Ecological Engineering, 24/5 (30 May 2005) pp. 433-439; D. Martino, Buffer Zones Around Protected Areas: A Brief Literature Review, Electronic Green Journal, $1 / 15$ (2001) URL: http://escholarship.org/uc/item/02n4v17n ; F. Götmark et al., Buffer Zones For Forest Reserves: Opinions Of Land Owners And Conservation Value Of Their Forest Around Nature Reserves In Southern Sweden, Biodiversity And Conservation 9/13 (2000) pp.77-1390; K. Redford, S. Sanderson, Extracting Humans from Nature, Conservation Biology, 14/5 (Oct., 2000) pp. 1362-1364; R. Schroeder, Geographies of environmental intervention in Africa, Progress in Human Geography 23/3 (1999) pp. 359-378; C. Shafer, US National Park Buffer Zones: Historical, Scientific, Social and Legal Aspects, Environmental Management 23/1 (1999) pp. 4973; A. de Sherbinin, M. Freudenberger, Migration To Protected Areas And Buffer Zones: Can We Stem The Tide?, Parks, 8/1 (February 1998) pp. 38-53; R.P. Neumann, Primitive Ideas: Protected Area Buffer Zones and the Politics of Land in Africa, Development and Change 28 (1997) pp. 559-582; V. Burke and J. Gibbons, Terrestrial Buffer Zones and Wetland Conservation: A Case Study of Freshwater Turtles in a Carolina Bay, Conservation Biology 9/6 (December 1995) pp. 1365-1369; Jongman, R.H.G.; Troumbis, A.Y., The Wider Landscape For Nature Conservation: Ecological Corridors And Buffer Zones; M. Wells and K.Brandon, The Principles and Practice of Buffer Zones and Local Participation in Biodiversity Conservation, Ambio Biodiversity: Ecology, Economics, Policy 22/2-3 (May, 1993) pp. 157-162; R. Mwalyosi, Ecological evaluation for wildlife corridors and buffer zones for Lake Manyara National Park, Tanzania, and its immediate environment, Biological Conservation Volume 57/2 (1991) pp. 171-186.

52. A.-L. Amilhat-Szary, S. Guyot, El turismo transfronterizo en los Andes centrales: prolegómenos sobre una geopolítica del turismo, Si Somos Americanos on press (2010).

${ }^{53}$ F.Giraut, S. Guyot, M. Houssay-Holzschuch, Les aires protégées dans les recompositions territoriales africaines", L'Information Géographique 68 (décembre 2004) pp 340-368.

54 . Amilhat-Szary, Guyot (note 38).

${ }^{55}$. N. Castree, Neoliberalising nature: processes, effects and evaluations, Environment and Planning A 40 (2008) pp. $153-173$.

56. Guyot (note 9); NGO “Conservation International”: http://www.biodiversityhotspots.org/Pages/default.aspx, accessed $23^{\text {rd }}$ of June 2010.

57. NGO "Survival": http://www.survivalfrance.org, accessed $23^{\text {rd }}$ of June 2010.

${ }^{58}$. NGO "IUCN": http://www.iucn.org, accessed $23^{\text {rd }}$ of June 2010.

${ }^{59}$. See the topic of the next BRIT Conference being held in Grenoble and Geneva in August 2011.

${ }^{60}$. C. Chester, Conservation Across Borders: Biodiversity in an Interdependant world (Washington, Covelo, London: Island Press, 2006); J. Fall, Planning Protected Areas Across Boundaries New Paradigms and Old Ghosts, Journal of Sustainable Forestry 17/1 (2003) pp. 81-102; J. Fall, Divide and rule: Constructing human boundaries in 'boundless nature', GeoJournal 58 (2002) pp. 243-251.

61. S. Guyot, Géopolitique des parcs (trans) frontaliers en Afrique Australe, Cahiers d'Outre Mer, 234 (printemps 2006) pp. 215-232.

${ }^{62}$. L. Pulido, Rethinking environmental racism: white privilege and urban development in southern California, Annals of the Association of American Geographers 90/1 (2000) pp.12-40.

${ }^{63}$. S. Cutter, S., Race, class and environmental justice, Progress in human Geography 19 (1995) pp.107-118; F. Khan, The Roots of Environmental Racism and the Rise of Environmental Justice in the 1990s, in D. McDonald (éd.), Environmental Justice in South Africa (Athens/Cape Town: Ohio University Press/UCT Press 2002) pp. 15-48.; R. Turner, D. Wu, Environmental justice and environmental racism, an annotated bibliography and general overview focusing on US literature, 1996-2002 (Berkeley: Institute of International Studies, University of California 2002); N. Ishiyama, N., Environmental justice and American Indian tribal sovereignty: case study of a land-use conflict in Skull Valley, Utah, Antipode, 35/1 (2003) pp. 119-139. 
${ }^{64}$. T.W. Luke, Towards a Green Geopolitics: Politicising Ecology at the Worldwatch Institute, in K. Dodds, Atkinson D., Geopolitical Traditions: A Century of Geopolitical Thought (London: Routledge 2000) pp. 353-371.

65. V. Shiva, The Greening of Global Reach, in G. Tuathail, S. Dalby and P. Routledge (eds.), The Geopolitics Reader (London: Routledge 1998) pp. 231-236.

${ }^{66}$. S. Kollin, Nature's State, Imagining Alaska as the last frontier (London: University of North Carolina Press 2001)

${ }^{67}$. "ECO FRONTIER JN" is an environment-friendly, chromate-free functional coated steel sheet for electrical appliances, which was developed by JFE Steel in response to environmental needs. By developing an organic composite coating consisting of an original organic resin with a high barrier effect and inorganic inhibitors with a self-healing effect, JFE realized high corrosion resistance with a thin film for the first time in the world and succeeded in satisfying the mutually contradictory requirements of corrosion resistance and electrical conductivity. Because "JN" has excellent properties, including corrosion resistance, corrosion resistance after alkaline degreasing, electrical grounding, weldability, anti-fingerprint properties, and paint adhesion properties, application in the internal parts of OA/AV equipment and electrical appliances is increasing. As related products, JFE Steel has also developed and commercialised various other functional chromate-free steel sheets in the "ECO FRONTIER" series, which provide higher levels of corrosion resistance, formability, paint adhesion, lubricity, and other properties. http://www.jfesteel.co.jp http://www.jfe-steel.co.jp/en/products/sheets/denki-aen/JD.html, accessed 22 June 2010.

68. All these ten keywords, both in English and French (eco-frontiers/eco-frontier/front écologique/frontière environnementale, conservation frontier, eco-settlers, eco-conquerors/éco-conquérants and eco-warriors/éco-guerriers), have been searched in Google over the last ten years. We have selected the twelve most representative websites to justify our argument.

${ }^{69}$. J. Aronson et al., Ecological restoration: A new frontier for nature conservation and economics, Journal for Nature Conservation, 4 (2006) pp. 135-139.

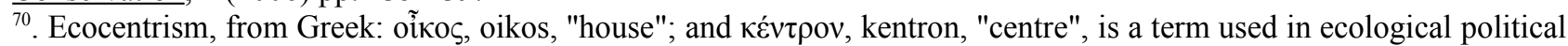
philosophy to denote a nature-centred, as opposed to human-centred, system of values. See: R. Eckersley, R., Environmentalism and Political Theory: Toward an Ecocentric Approach (New York: State University of New York Press 1992).

${ }^{71}$. "The goal of Dancing Star Foundation is to help sensitise people throughout the world to the critical importance of biodiversity and conservation; and to instil a respect for all life, which can be demonstrated by even the most modest gestures of kindness, compassion, and love in our everyday lives." http://www.dancingstarfoundation.org/photos.php Accessed 12/05/2009.

72. M. Tobias http://www.dancingstarfoundation.org/pdfs/articles/Deep demography.pdf, accessed 12/05/2009; M. Tobias et al. (eds.), No Vacancy: Global Responses to the Human Population Explosion (Pasadena: Hope Publishing 2006).

73. Thoreau was deeply interested in the idea of survival in the face of hostile elements, historical change, and natural decay, at the same time imploring people to abandon waste and illusion in order to discover life's true essential needs.

74. M. Onfray, Théorie du Voyage (Paris : Essais Poche 2007).

75 . T. Forsyth, What happened on The Beach? Social movements and governance of tourism in Thailand, International Journal of Sustainable Development, 5/3 (2002) pp. 326-337.

${ }^{76}$. J. Lovelock, La Terre est un être vivant, l'hypothèse Gaïa (Paris : Flammarion, coll. « Champs » 1999).

${ }^{77}$ http://www.fairfaxfederation.org/bulletin/FCFCAbulletin0709.pdf Accessed 12/05/2009.

${ }^{78}$. Guyot et Dellier (note 9).

${ }^{79}$. H. Collinson, Green Guerillas: environmental conflicts and initiatives in Latin America and the Caribbean. (London: Latin America Bureau 1996); M. Honey, Ecotourism and sustainable development: who owns paradise? (Washington: Island Press 1999); Compagnon, Constantin, 2000 D. Compagnon, F. Constantin, Administrer l'environnement en Afrique (Paris, Nairobi : Karthala, IFRA 2000); S. Dovers, R. Edgecombe, B. Guest, South Africa's environmental history: cases and comparisons (Athens and Cape Town: Ohio University Press and David Philip Publishers 2002); G. Hilson, An overview of land use conflicts in mining communities. Land use policy 19 (2002) pp.65-73; C. Fabricius, E. Koch, S. Turner, H. Magoma, Rights, Resources and Rural Development: community-based natural resource management in Southern Africa (Cape Town: Earthscan 2004); M. Ramutsindela, Parks and people in postcolonial societies: experiences in Southern Africa. (Dordrecht: Kluwer Academic Publishers 2004).

${ }^{80}$. Guyot et Dellier (note 9).

${ }^{81}$. M. Honey, Ecotourism and sustainable development: who owns paradise? (Washington: Island Press 1999).

${ }^{82}$. "Green Geopolitics" in J.Agnew, K. Mitchell and G. Ó Tuathail (eds), A Companion Guide to Political Geography Oxford (Oxford: Blackwell 2003) pp. 440-454.

${ }^{83}$. T. Kuehls, Beyond sovereign territory: the space of ecopolitics, (Minneapolis, Minnesota Press, 1996).

${ }^{84}$. See note 44 .

${ }^{85}$. Environmental Justice Networking Forum. See http://www.bcb.uwc.ac.za/inforeep/EJNF.htm, accessed 10/12/2009.

${ }^{86}$. See http://www.foxnews.com/story/0,2933,343768,00.html, accessed 11/05/2009. 